\title{
FAKTOR - FAKTOR RISIKO YANG BERHUBUNGAN DENGAN KEJADIAN PENYAKIT JANTUNG KORONER (PJK) PADA USIA DEWASA DI RS HAJI JAKARTA
}

\author{
Ilah Muhafilah", ${ }^{1)}$ Vivin Febi Saputri ${ }^{2)}$ \\ Program studi S1 Keperawatan Universitas MH Thamrin \\ Ilah_akn@yahoo.com
}

\begin{abstract}
ABSTRAK
Penyakit jantung koroner (PJK) merupakan suatu gangguan jantung dan pembuluh darah dimana tejadi penyempitan pembuluh darah koroner yang terjadi karena adanya plak pada seluruh arteri sehingga mengurangi aliran darah ke jantung. Penelitian ini bertujuan untuk mengidentifikasi faktor risiko yang berhubungan dengan kejadian PJK pada usia dewasa di RS Haji Jakarta, dengan variabel independen yaitu riwayat keluarga, jenis kelamin, hipertensi, hiperkolesterolemia, merokok, diabetes, dan obesitas, sedangkan variabel dependen yaitu PJK pada usia dewasa.Desain penelitian adalah kuantitatif deskriptif analitik dengan pendekatan Cross Sectional.Populasi semua pasien PJK yang menjalani rawat inap (Syifa dan Afiah), serta rawat jalan poli klinik jantung di RS Haji Jakarta.Jumlah responden yang sesuai dengan kriteria inklusi sebanyak 61 responden diambil dengan menggunakan consecutive sampling. Instrumen yang digunakan berupa kuesioner. Hasil penelitian menunjukan analisa bivariat riwayat keluarga $(\mathrm{p}$-value $=0,027)$, jenis kelamin $(\mathrm{p}$-value $=$ 0,000), hipertensi ( $\mathrm{p}$-value $=0,007)$, merokok ( $\mathrm{p}$-value $=0,000)$, dan hiperkolesterolemia $(\mathrm{p}$-value $=0,000)$ merupakan faktor yang berhubungan dengan kejadian PJK pada usia dewasa. Ada hubungan yang signifikan antara riwayat keluarga,jenis kelamin,hipertensi,merokok, hiperkolesterolemia dengan kejadian PJK pada usia dewasa . Perawat dapat melakukan pendidikan kesehatan mengenai faktor risiko PJK pada klien di poliklinik jantung sehingga diharapkan dapat mengurangi kejadian PJK dan mencegah komplikasinya.
\end{abstract}

Kata Kunci: Penyakit Jantung Koroner (PJK), Usia Dewasa, Faktor Risiko

\section{PENDAHULUAN}

Penyakit Jantung Koroner (PJK) disebabkan oleh penimbunan plak pada arteri koroner baik kanan maupun kiri atau cabang-cabangnya. Penimbunan plak ini mengurangi aliran darah ke jantung.Sehingga asupan oksigen yang dibutuhkan jatung tidak tercukupi saat jantung bekerja (Freeman, 2008).PJK merupakan suatu penyakit karena penyempitan pembuluh darah yang membawa oksigen ke otak.Penyempitan pembuluh darah terjadi karena adanya plak pada seluruh arteri. Pembentukan plaques ini dapat menyertai dari faktor genetik dan gaya hidup (Irianto, 2014).

Faktor-faktor risiko terjadinya PJK ialah tingginya kadar kolesterol, tingginya tekanan darah, riwayat keluarga, diabetes, merokok, jenis kelamin, dan obesitas (American Heart Association, 2015). Anies (2015) menjelaskan bahwa faktor risiko PJK terbagi menjadi 2, yaitu faktor risiko yang tidak dapat diubah dan faktor risiko yang dapat diubah.Faktor risiko yang tidak dapat diubah adalah penderita PJK sebelumnya, umur, riwayat PJK dalam keluarga, jenis kelamin laki-laki, etnis.Sedangkan faktor risiko yang dapat diubah adalah kolesterol tinggi, merokok, tekanan darah tinggi, diabetes melitus, obesitas, pola makan tidak sehat, kurang aktivitas fisik, serta gangguan pembekuan darah.

Lebih dari 82 juta orang Amerika memiliki PJK, dan setiap tahunnya lebih dari 813.000 orang meninggal karena PJK yang dialaminya (AHA, 2012). Prevalensi penyakit jantung koroner (PJK) berdasarkan wawancara yang didiagnosis dokter serta yang didiagnosis dokter atau gejala meningkat seiring dengan bertambahnya umur, tertinggi pada kelompok umur $65-74$ tahun yaitu 2,0 persen dan 3,6 persen, menurun sedikit pada kelompok umur $\geq 75$ tahun. Prevalensi PJK yang didiagnosis dokter maupun berdasarkan diagnosis dokter atau gejala lebih tinggi pada perempuan $(0,5 \%$ dan $1,5 \%)$. Prevalensi PJK lebih tinggi pada masyarakat tidak 
bersekolah dan tidak bekerja. Berdasarkan PJK terdiagnosis dokter prevalensi lebih tinggi di perkotaan, namun berdasarkan terdiagnosis dokter dan gejala lebih tinggi di perdesaan dan pada kuintil indeks kepemilikan terbawah (Riskesdas, 2013). Menurut Dirjen PP\&PL Kemenkes RI (2011), diperkirakan kematian jantung dan pembuluh darah meningkat menjadi 20 juta pada tahun 2015. Berdasarkan data rekam medis Rumah Sakit Cipto Mangunkusumo (Anissa, 2012) jumlah kunjungan pasien Poliklinik rawat jalan divisi jantung tahun 2009 sebanyak 9.837 pasien. Data rekam medis Rumah Sakit Pelni Jakarta jumlah kunjungan pasien rawat jalan tahun 2010 sebanyak 130.756 pasien, dan 10.525 diantaranya merupakan pasien yang berobat ke Poliklinik Jantung dengan berbagai permasalahan kardiovaskular (Rochmayanti, 2011). Berdasarkan studi pendahuluan yang dilakukan peneliti di RS Haji Jakarta didapatkan data bahwa angka kejadian PJK di RS Haji Jakarta pada bulan Januari - Desember 2014 sebanyak 2807 pasien, dan pada bulan Januari - April 2015 didapatkan sebanyak 128 pasien PJK.

Gray et al.,(2005), Freideriki et al., (2008), dan Trevoy (2009) dalam Indrawati (2012) menyatakan bahwa risiko PJK meningkat sejalan dengan peningkatan tekanan darah. Faktor risiko yang paling dominan adalah pria yang merokok dilanjutkan dengan hiperkolesterolmia. Merokok akan menyebabkan penurunan kadar oksigen ke jantung, peningkatan tekanan darah dan denyut nadi, penurunan HDL, peningkatan penggumpalan darah dan kerusakan endotel pembuluh darah koroner yang disebabkan oleh kandungan racun seperti tar, nikotin, dan karbon monoksida. Penumpukan lemak dibagian sentral tubuh juga akan meningkatkan risiko terjadin ya PJK. Kurang aktivitas fisik dan pola makan yang tidak sehat juga memicu terjadinya PJK. Aktivitas fisik akan memperbaiki sistem kerja jantung dan pembuluh darah dengan meningkatkan efisiensi kerja jantung. Pola makan yang tidak sehat berhubungan dengan sajian yang tidak sehat, karena mengandung kalori, lemak, protein tinggi, dan garam tinggi sehingga mengarah pada kondisi obesitas (PP\&PL, Kemenkes RI, 2011). Mawi (2003) dalam Indrawati (2012) menyatakan bahwa hubungan Indeks Massa Tubuh dengan PJK dinyatakan bahwa prevalensi PJK akan semakin meningkat seiring dengan meningkatnya IMT terutama pada perempuan. Shabbir et al., (2004) dalam Rosmiatin (2012) menyatakan bahwa faktor risiko PJK pada lansia berbeda dengan pada usia yang lebih muda. Faktor risiko yang dominan dalam studi tersebut adalah hipertensi $(89,8 \%)$, diabetes melitus $(58,1 \%)$, gagal jantung $(25,9 \%)$, dan riwayat PJK (39,5\%). Berdasarkan beberapa fenomena maka peneliti tertarik meneliti tentang faktor risiko yang berhubungan dengan kejadian PJK pada usia dewasa di Rumah Sakit Haji Jakarta.

\section{METODE}

Penelitian ini merupakan penelitian kuantitatif yang menggunakan metode penelitian deskriptif analitik.Deskriptif analitik merupakan penelitian yang bertujuan untuk memaparkan variabel penelitian deskriptif, kemudian dilakukan analisa untuk mengetahui adanya hubungan variabel variabel yang diteliti (Dharma, 2013). Penelitian ini menggunakan pendekatan studi cross sectional yang dapat diartikan bahwa peneliti melakukan pengukuran atau penelitian dalam satu waktu (Dharma, 2013).

Populasi dalam penelitian ini adalah semua pasien PJK yang menjalani rawat inap (Syifa dn Afiah), serta rawat jalan poliklinik jantung di RS Haji Jakarta. Jumlah responden di ruang rawat inap dan poliklinik jantung di RS 
Haji Jakarta yang sesuai dengan kriteria inklusi sebanyak 61 responden diambil dengan menggunakan consecutive sampling.

1. Kriteria inklusi sampel pada penelitian ini adalah :
a. Pasien PJK yang sedang menjalani rawat jalan dan rawat inap di RS Haji Jakarta.
b. Usia pasien $\geq 20$ tahun.
c. Mampu membaca dan menulis.
d. Bersedia menjadi responden.

2. Kriteria eksklusi yang menyebabkan subjek yang memenuhi kriteria inklusi tidak dapat diikutsertakan dalam penelitian ini antara lain :

a. Pasien PJK mengalami nyeri dada, dan sesak.

b. Terjadi penurunan status kesehatan secara drastis.

Proses pengumpulan data peneliti melakukan editing dengan melakukan pengecekan kuesioner terjawab lengkap atau tidak, jawaban dapat terbaca jelas atau tidak, dan apakah jawaban relevan dengan pertanyaan yang dilakukan setelah setiap responden mengisi kuesioner. Codingdenganmengubah data berbentuk huruf menjadi data angka dan Processing dengan menganalisa data dengan menggunakan program pengolahan angka dalam komputer, serta Cleaningdenganmemeriksa kembali untuk melihat adanya kesalahan saat pengkodean dan memastikan bahwa data yangdimasukkan benar.

Berikut merupakan analisis data yang digunakan pada penelitian ini:

\section{Analisis Univariat}

Analisis univariat merupakan analisa yang dilakukan untuk menganalisa tiap variabel dari hasil penelitian.Variabel independen pada penelitian ini yaitu riwayat keluarga, jenis kelamin, hipertensi, hiperkolesterolemia, merokok, diabetes, obesitas. Variabel dependen yang akan diteliti adalah kejadian PJK pada usia dewasa.

1. Analisis Bivariat

Analisis bivariat digunakan untuk melihat kemungkinan hubungan antara variabel independen dan variabel dependen dengan menggunakan analisis uji chi-square.

\section{HASIL DAN PEMBAHASAN}

\section{Analisis Univariat}

Hasil analisa menunjukkan bahwa sebagian besar responden mengalami PJK pada usia dewasa menengah - akhir sebanyak 45 responden $(73,8 \%)$, memiliki riwayat keluarga dengan PJK sebanyak 37 responden $(60,7 \%)$, berjenis kelamin perempuan sebanyak 40 responden $(65,6 \%)$, mengalami hipertensi sebanyak 33 responden $(54,1 \%)$, responden tidak merokok sebanyak 40 responden $(65,6 \%)$, mengalami hiperkolesterolemia sebanyak 35 responden $(57,4 \%)$, responden tidak mengalami diabetes melitus sebanyak 42 responden $(68,9 \%)$, dan tidak mengalami obesitas sebanyak 53 responden $(86,9 \%)$. 


\section{Tabel 1}

Distribusi Frekuensi PJK Berdasarkan usia, riwayat keluarga, jenis kelamin, hipertensi, merokok, hiperkolesterolemia, diabetes, dan obesitas di RS Haji Jakarta (n=61)

\begin{tabular}{|c|c|c|}
\hline Variabel & $\mathbf{N}$ & $\%$ \\
\hline \multicolumn{3}{|l|}{ Dependen } \\
\hline Dewasa Awal & 16 & 26,2 \\
\hline Dewasa Menengah-Akhir & 45 & 73,8 \\
\hline \multicolumn{3}{|l|}{ Independen } \\
\hline $\mathrm{Ya}$ & 37 & 60,7 \\
\hline Tidak & 24 & 39,3 \\
\hline Total & 61 & 100 \\
\hline \multicolumn{3}{|l|}{ Jenis Kelamin } \\
\hline Laki-laki & 21 & 34,4 \\
\hline Perempuan & 40 & 65,6 \\
\hline \multicolumn{3}{|l|}{ Hipertensi } \\
\hline $\mathrm{Ya}$ & 33 & 54,1 \\
\hline Tidak & 28 & 45,9 \\
\hline \multicolumn{3}{|l|}{ Merokok } \\
\hline $\mathrm{Ya}$ & 21 & 34,4 \\
\hline Tidak & 40 & 65,6 \\
\hline Variabel & $\mathbf{N}$ & $\%$ \\
\hline \multicolumn{3}{|l|}{ Hiperkolesterolemia } \\
\hline $\mathrm{Ya}$ & 35 & 57,4 \\
\hline Tidak & 26 & 42,6 \\
\hline Total & 61 & 100 \\
\hline \multicolumn{3}{|l|}{ Diabetes Melitus } \\
\hline $\mathrm{Ya}$ & 19 & 31,1 \\
\hline Tidak & 42 & 68,9 \\
\hline Total & 61 & 100 \\
\hline \multicolumn{3}{|l|}{ Obesitas } \\
\hline $\mathrm{Ya}$ & 8 & 13,1 \\
\hline Tidak & 53 & 86,9 \\
\hline Total & 61 & 100 \\
\hline
\end{tabular}

\section{Analisis Bivariat}

Hasil analisis hubungan antara riwayat keluarga dengan kejadian PJK menunjukkan bahwa responden yang memiliki riwayat keluarga PJK mengalami PJK pada usia dewasa menengah - akhir sebesar 31 orang (83,3\%), sedangkan responden yang tidak memiliki riwayat keluarga PJK mengalami PJK pada usia dewasa menengah - akhir sebesar 14 orang $(58,3 \%)$. Hasil uji statistik menunjukkan ( $p$ value $=0,027$ ) bahwa adanya hubungan antara riwayat keluarga dengan kejadian PJK pada usia dewasa menengah - akhir. Hasil analisa diperoleh pula nilai $\mathrm{OR}=3,690$, artinya responden yang memiliki riwayat keluarga PJK mempunyai peluang 3,690 kali mengalami PJK di usia dewasa menengah - akhir dibandingkan dengan responden yang tidak memiliki riwayat keluarga dengan PJK. 
Tabel 2

Hubungan Riwayat Keluarga Dengan Kejadian PJK Pada Usia Dewasa di RS Haji Jakarta $(n=61)$

\begin{tabular}{|c|c|c|c|c|c|c|c|c|}
\hline \multirow{3}{*}{ Variabel } & \multicolumn{4}{|c|}{ PJK } & \multirow{2}{*}{\multicolumn{2}{|c|}{ Total }} & \multirow{3}{*}{$\begin{array}{c}O R \\
95 \% \mathrm{CI}\end{array}$} & \multirow{3}{*}{ p Value } \\
\hline & \multicolumn{2}{|c|}{ Usia Dewasa Awal } & \multicolumn{2}{|c|}{$\begin{array}{c}\text { Usia Dewasa } \\
\text { Menengah -Akhir }\end{array}$} & & & & \\
\hline & $\mathrm{N}$ & $\%$ & $\mathrm{~N}$ & $\%$ & $\mathrm{~N}$ & $\%$ & & \\
\hline \multicolumn{9}{|l|}{ Riwavat Keluarga } \\
\hline Ya & 6 & 16,2 & 31 & 83,8 & 37 & 100 & 3,690 & \\
\hline Tidak & 10 & 41,7 & 14 & 58,3 & 24 & 100 & 1,120 & \\
\hline Total & 16 & 26,2 & 45 & 73,8 & 61 & 100 & 12,165 & 0,027 \\
\hline \multicolumn{9}{|l|}{ Jenis Kelamin } \\
\hline Ya & 15 & 71,4 & 6 & 28,6 & 21 & 100 & 97,500 & \\
\hline Tidak & 1 & 2,5 & 39 & 97,5 & 40 & 100 & 10,812 & \\
\hline Total & 16 & 26,2 & 45 & 73,8 & 61 & 100 & 879,199 & $\underline{0,000}$ \\
\hline \multicolumn{9}{|l|}{ Hipertensi } \\
\hline Ya & 4 & 12,1 & 29 & 87,9 & 33 & 100 & 5,438 & \\
\hline Tidak & 12 & 42,9 & 16 & 57,1 & 28 & 100 & 1,503 & \\
\hline Total & 16 & 26,2 & 45 & 73,8 & 61 & 100 & 19.669 & $\underline{0,007}$ \\
\hline \multicolumn{9}{|l|}{ Merokok } \\
\hline Ya & 15 & 71,4 & 6 & 28,6 & 21 & 100 & 0,010 & \\
\hline Tidak & 1 & 2,5 & 39 & 97,5 & 40 & 100 & 0,001 & \\
\hline Total & 16 & 26,2 & 45 & 73,8 & 61 & 100 & 0,092 & $\underline{0,000}$ \\
\hline \multicolumn{9}{|l|}{ Hiperkolesterolemia } \\
\hline Ya & 2 & 5,7 & 33 & 94,3 & 35 & 100 & 19,250 & \\
\hline Tidak & 14 & 53,8 & 12 & 46,2 & 26 & 100 & 3,801 & 0000 \\
\hline Total & 16 & 26,2 & 45 & 73,8 & 61 & 100 & 97,490 & 0,000 \\
\hline
\end{tabular}

Hasil analisis hubungan antara jenis kelamin dengan kejadian PJK menunjukkan bahwa responden dengan jenis kelamin perempuan mengalami PJK pada usia dewasa menengah - akhir sebesar 39 orang (97,5\%), sedangkan responden laki-laki mengalami PJK pada usia dewasa menengah - akhir sebesar 6 orang $(28,6 \%)$. Hasil uji statistik menunjukkan ( $p$ value $=0,000$ ) bahwa adanya hubungan antara jenis kelamin dengan kejadian PJK pada usia dewasa menengah - akhir. Hasil analisa diperoleh nilai $\mathrm{OR}=97,500$, artinya responden perempuan mempunyai peluang 97,500 kali mengalami PJK di usia dewasa menengah - akhir dibandingkan dengan responden laki-laki.

Hasil analisis hubungan antara hipertensi dengan kejadian PJK menunjukkan bahwa responden dengan hipertensi yang mengalami PJK pada usia dewasa menengah - akhir sebesar 29 orang (87,5\%), sedangkan responden dengan tidak hipertensi yang mengalami PJK pada usia dewasa menengah - akhir sebesar 16 orang $(57,1 \%)$. Hasil uji statistik menunjukkan $(p$ value $=0,007$ ) bahwa adanya hubungan antara hipertensi dengan kejadian PJK pada usia dewasa menengah - akhir. Hasil analisa diperoleh nilai OR=5,438, artinya responden dengan hipertensi mempunyai peluang 5,438 kali untuk mengalami PJK di usia dewasa menengah - akhir dibandingkan dengan responden yang tidak hipertensi.

Hasil analisis hubungan antara merokok dengan kejadian PJK menunjukkan bahwa responden yang merokok dan mengalami PJK pada usia dewasa menengah - akhir sebesar 6 orang (28,6\%), sedangkan responden yang tidak merokok dan mengalami PJK pada usia dewasa menengah - akhir sebesar 39 orang $(97,5 \%)$. Hasil uji statistik menunjukkan ( $p$ value $=0,000$ ) bahwa adanya hubungan antara merokok dengan kejadian PJK pada usia dewasa menengah - akhir. Hasil analisa diperoleh nilai $\mathrm{OR}=0,010$, artinya responden 
yang merokok mempunyai peluang 0,010 kali untuk mengalami PJK di usia dewasa menengah - akhir dibandingkan dengan responden yang tidak merokok.

Hasil analisis hubungan antara hiperkolesterolemia dengan kejadian PJK menunjukkan bahwa responden dengan hiperkolesterolemia dan mengalami PJK pada usia dewasa menengah - akhir sebesar 33 orang (94,3\%), sedangkan responden yang tidak hiperkolesterolemia dan mengalami PJK pada usia dewasa menengah - akhir sebesar 12 orang $(46,2 \%)$. Hasil uji statistik menunjukkan ( $p$ value $=0,000$ ) bahwa adanya hubungan antara hiperkolesterolemmia dengan kejadian PJK pada usia dewasa menengah-akhir. Hasil analisa diperoleh nilai $\mathrm{OR}=19,250$, artinya responden dengan hiperkolesterolemia mempunyai peluang 19,250 untuk mengalami PJK di usia dewasa menengah - akhir dibandingkan dengan responden yang tidak hiperkolesterolemia.

Hasil penelitian menunjukkan bahwa dari jumlah 61 responden didapatkan angka kejadian PJK lebih besar pada usia dewasa menengah - akhir yaitu 45 orang (73,8\%), 37 orang (60,7\%) memiliki riwayat keluarga dengan PJK, 40 orang $(65,6 \%)$ PJK dialami oleh perempuan dan 21 orang $(34,4 \%)$ pada laki-laki, 33 orang $(54,1 \%)$ yang mengalami hipertensi, 21 orang $(34,4 \%)$ merokok, 35 orang $(57,4 \%)$ mengalami hiperkolesterolemia, 19 orang $(31,1 \%)$ mengalami diabetes melitus, dan 8 orang $(13,1 \%)$ mengalami obesitas.

Hasil analisis hubungan antara riwayat keluarga dengan kejadian PJK menunjukkan bahwa responden yang memiliki riwayat keluarga PJK mengalami PJK pada usia dewasa menengah - akhir sebesar 31 orang (83,3\%), sedangkan responden yang tidak memiliki riwayat keluarga PJK mengalami PJK pada usia dewasa menengah - akhir sebesar 14 orang $(58,3 \%)$. Hasil uji statistik menunjukkan ( $p$ value $=0,027$ ) bahwa adanya hubungan antara riwayat keluarga dengan kejadian PJK pada usia dewasa menengah - akhir. Hasil analisa diperoleh pula nilai $\mathrm{OR}=3,690$, artinya responden yang memiliki riwayat keluarga PJK mempunyai peluang 3,690 kali mengalami PJK di usia dewasa menengah - akhir dibandingkan dengan responden yang tidak memiliki riwayat keluarga dengan PJK. Hasil penelitian ini sejalan dengan penelitian yang dilakukan oleh Rosmiatin (2012) tentang analisis faktor-faktor risiko terhadap kejadian penyakit jantung koroner pada wanita usia lanjut yang menyatakan bahwa terdapat hubungan antara riwayat keluarga dengan kejadian PJK dengan $p$ value $=0,026(\alpha \leq 0,05)$, menunjukkan bahwa riwayat keluarga berpengaruh dengan kejadian PJK. Hasil penelitian ini sesuai dengan teori Gray (2005) yang menyatakan bahwa riwayat keluarga PJK pada keluarga yang berhubungan darah dengan anggota lain yang berusia kurang dari 70 tahun memiliki risiko terjadinya PJK. Teori Soeharto (2001) menyatakan bahwa keluarga yang memiliki anggota keluarga yang menderita PJK dibawah umur 55 tahun, menunjukkan bahwa ada anggota lain dari keluarga tersebut yang memiliki penyakit jantung yang bersifat prematur yaitu seseorang yang penyakit jantung dibawah umur 55 tahun.

Hasil analisis hubungan antara jenis kelamin dengan kejadian PJK menunjukkan bahwa responden dengan jenis kelamin perempuan mengalami PJK pada usia dewasa menengah - akhir sebesar 39 orang (97,5\%), sedangkan responden laki-laki mengalami PJK pada usia dewasa menengah - akhir sebesar 6 orang (28,6\%). Hasil uji statistik menunjukkan ( $p$ value $=0,000$ ) bahwa adanya hubungan antara jenis kelamin dengan kejadian PJK pada usia dewasa menengah - akhir. Hasil analisa diperoleh nilai OR=97,500, artinya responden perempuan mempunyai peluang 97,500 kali mengalami PJK di usia dewasa menengah - akhir dibandingkan dengan responden laki-laki. Hasil penelitian ini sejalan dengan penelitian yang dilakukan oleh Rochmayanti (2011) tentang analisis faktor-faktor yang mempengaruhi kualitas hidup pasien penyakit jantung koroner yang 
menyatakan bahwa terdapat hubungan antara jenis kelamin dengan kejadian PJK dengan $p$ value $=0,006$ ( $\alpha \leq$ 0,05), menunjukkan bahwa jenis kelamin berpengaruh dengan kejadian PJK. Gray (2005) menyatakan bahwa laki - laki 2 kali lebih besar dari perempuan dalam angka morbiditas akibat PJK. Kondisi ini terjadi dalam 10 tahun lebih dini dari perempuan. Perempuan memiliki hormon estrogen yang berfungsi sebagai protektif dari PJK, namun setelah terjadi menopause pada perempuan maka terjadi peningkatan PJK dengan cepat

Hasil analisis hubungan antara hipertensi dengan kejadian PJK menunjukkan bahwa responden dengan hipertensi yang mengalami PJK pada usia dewasa menengah - akhir sebesar 29 orang (87,5\%), sedangkan responden dengan tidak hipertensi yang mengalami PJK pada usia dewasa menengah - akhir sebesar 16 orang $(57,1 \%)$. Hasil uji statistik menunjukkan ( $p$ value $=0,007$ ) bahwa adanya hubungan antara hipertensi dengan kejadian PJK pada usia dewasa menengah - akhir. Hasil analisa diperoleh nilai $\mathrm{OR}=5,438$, artinya responden dengan hipertensi mempunyai peluang 5,438 kali untuk mengalami PJK di usia dewasa menengah - akhir dibandingkan dengan responden yang tidak hipertensi. Hasil penelitian ini tidak sejalan dengan penelitian yang dilakukan oleh Rosmiatin (2012) tentang analisis faktor-faktor risiko terhadap kejadian penyakit jantung koroner pada wanita usia lanjut yang menyatakan bahwa tidak ada hubungan antara hipertensi dengan kejadian PJK dengan $p$ value $=0,72(\alpha \leq 0,05)$, menunjukkan bahwa hipertensi tidak berpengaruh dengan kejadian PJK. Freeman (2008) menyatakan bahwa seseorang yang memiliki hipertensi kemungkinan 2 kali lebih besar untuk terkena PJK daripada seseorang yang memiliki tekanan darah yang normal.

Hasil analisis hubungan antara merokok dengan kejadian PJK menunjukkan bahwa responden yang merokok dan mengalami PJK pada usia dewasa menengah - akhir sebesar 6 orang (28,6\%), sedangkan responden yang tidak merokok dan mengalami PJK pada usia dewasa menengah - akhir sebesar 39 orang $(97,5 \%)$. Hasil uji statistik menunjukkan $(p$ value $=0,000$ ) bahwa adanya hubungan antara merokok dengan kejadian PJK pada usia dewasa menengah - akhir. Hasil analisa diperoleh nilai $\mathrm{OR}=0,010$, artinya responden yang merokok mempunyai peluang 0,010 kali untuk mengalami PJK di usia dewasa menengah - akhir dibandingkan dengan responden yang tidak merokok. Hasil penelitian ini sejalan dengan penelitian yang dilakukan oleh Andarmoyo (2012) tentang faktor resiko kejadian PJK pada kelompok usia muda yang menyatakan bahwa ada hubungan antara kebiasaan merokok pada kelompok usia muda dengan kejadian PJK dengan $p$ value $=0,038(\alpha \leq 0,05)$, menunjukkan bahwa kebiasaan merokok pada kelompok usia muda berpengaruh dengan kejadian PJK. Hasil penelitian ini tidak sejalan dengan penelitian yang dilakukan oleh Rosmiatin (2012) tentang analisis faktor-faktor risiko terhadap kejadian penyakit jantung koroner pada wanita usia lanjut yang menyatakan bahwa tidak ada hubungan antara merokok dengan kejadian PJK dengan $p$ value $=$ 0,11 $(\alpha \leq 0,05)$, menunjukkan bahwa merokok tidak berpengaruh dengan kejadian PJK. Jackson (2009) menyatakan bahwa perokok aktif berisiko 2 kali lipat terkena PJK dibandingkan bukan perokok. Menurut Freeman (2008) merokok bertanggung jawab atas $20 \%$ dari semua kematian akibat penyakit arteri koroner. Untuk seseorang yang sudah setahun berhenti merokok, risikonya berkurang sampai separuhnya. Dalam waktu 2 tahun, risikonya hampir sama dengan orang yang tidak pernah merokok.

Hasil analisis hubungan antara hiperkolesterolemia dengan kejadian PJK menunjukkan bahwa responden dengan hiperkolesterolemia dan mengalami PJK pada usia dewasa menengah - akhir sebesar 33 orang (94,3\%), sedangkan responden yang tidak hiperkolesterolemia dan mengalami PJK pada usia dewasa menengah - akhir 
sebesar 12 orang $(46,2 \%)$. Hasil uji statistik menunjukkan $(p$ value $=0,000)$ bahwa adanya hubungan antara hiperkolesterolemmia dengan kejadian PJK pada usia dewasa menengah - akhir. Hasil analisa diperoleh nilai $\mathrm{OR}=19,250$, artinya responden dengan hiperkolesterolemia mempunyai peluang 19,250 untuk mengalami PJK di usia dewasa menengah - akhir dibandingkan dengan responden yang tidak hiperkolesterolemia. Hasil penelitian ini sejalan dengan penelitian yang dilakukan oleh Rosmiatin (2012) tentang analisis faktor-faktor risiko terhadap kejadian penyakit jantung koroner pada wanita usia lanjut yang menyatakan bahwa ada hubungan yang signifikan antara dislipidemia dengan kejadian PJK ( $p$ value $=0,00$ ). Hasil penelitian ini tidak sejalan dengan penelitian yang dilakukan oleh Supriyono (2008) tentang faktor-faktor risiko yang berpengaruh terhadap kejadian penyakit jantung koroner pada kelompok usia $\leq 45$ tahun yang menyatakan bahwa tidak ada hubungan yang bermakna antara kenaikan kadar kolesterol dalam darah dengan kejadian PJK ( $p$ value $=0,082$ ).

Hasil penelitian ini sesuai dengan teori Anies (2015) yang menyatakan bahwa tingginya kadar kolesterol dalam tubuh juga menimbulkan efek tidak baik karena dapat menyebabkan terjadinya penyempitan tersumbatnya pembuluh darah arteri. Penyempitan pada arteri koroner mengakibatkan aliran darah ke otot jantung berkurang atau berhenti sama sekali sehingga terjadilah PJK.

\section{KESIMPULAN DAN SARAN}

Dalam penelitian ini diketahui sebagian besar responden mengalami PJK pada usia dewasa menengah akhir sebanyak 45 responden $(73,8 \%)$. Sebagian besar responden memiliki riwayat keluarga dengan PJK sebanyak 37 responden $(60,7 \%)$. Sebagian besar responden berjenis kelamin perempuan sebanyak 40 responden (65,6\%). Sebagian besar responden mengalami hipertensi sebanyak 33 responden $(54,1 \%)$. Sebagian besar responden tidak merokok sebanyak 40 responden (65,6\%). Sebagian besar responden mengalami hiperkolesterolemia sebanyak 35 responden $(57,4 \%)$. Sebagian besar responden tidak mengalami diabetes melitus sebanyak 42 responden $(68,9 \%)$. Sebagian besar responden tidak mengalami obesitas sebanyak 53 responden (86,9\%); Ada hubungan yang signifikan antara riwayat keluarga dengan kejadian PJK pada usia dewasa ( $p$ value $=0,027, \mathrm{OR}=3,690(95 \% \mathrm{CI}=1,120-12,165)$ ); Ada hubungan yang signifikan antara jenis kelamin dengan kejadian PJK pada usia dewasa ( $p$ value $=0,000, \mathrm{OR}=97,500(95 \% \mathrm{CI}=10,812-879,199)$ ); Ada hubungan yang signifikan antara hipertensi dengan kejadian PJK pada usia dewasa $(p$ value $=0,007, \mathrm{OR}=$ $5,438(95 \% \mathrm{CI}=1,503-19,669))$; Ada hubungan yang signifikan antara merokok dengan kejadian PJK pada usia dewasa ( $p$ value $=0,000, \mathrm{OR}=0,010(95 \% \mathrm{CI}=0,001-0,092)$ ); Ada hubungan yang signifikan antara hiperkolesterolemia dengan kejadian PJK pada usia dewasa ( $p$ value $=0,000, \mathrm{OR}=19,250$ (95\% CI $=3,801$ 97,490)). Penelitian ini merekomendasikan perawat dapat melakukan pendidikan kesehatan kepada pasien poliklinik jantung mengenai faktor-faktor risiko apa saja yang dapat menyebabkan terjadinya PJK, sehingga diharapkan dapat mengurangi kejadian PJK dari berbagai faktor yang mempengaruhinya dan dapat mencegah terjadinya komplikasi dari PJK. 


\section{UCAPAN TERIMAKASIH}

Terima kasih kepada Ka. Instalasi Diklat RS Haji Jakarta Bpk. Ns. Turiman, S.Kep yang telah memberikan ijin kepada peneliti untuk melakukan studi pendahuluan dan penelitian di RS Haji Jakarta.

\section{DAFTAR PUSTAKA}

1. Andarmoyo, Sulistyo. (2012). Faktor Resiko Kejadian PJK (Penyakit Jantung Koroner) Pada Kelompok Usia Muda. Penelitian Dosen Pemula. Ponorogo: Program Studi DIII Keperawatan Fakultas Ilmu Kesehatan Universitas Muhammadiyah Ponorogo

2. Anies.(2015). Kolesterol \& Penyakit Jantung Koroner. Jogjakarta: Ar-Ruzz Media

3. Anissa Febriani, Valentina. (2012). Analisis Pengaruh Kualitas Pelayanan Terhadap Kepuasan Konsumen.Skripsi. Semarang: Program Sarjana Fakultas Ekonomika dan Bisnis Universitas Diponegoro

4. Freeman, Mason W., \& Junge, C (2008) .Kolesterol Rendah Jantung Sehat (cet. ke-2). Jakarta: Bhuana Ilmu Populer

5. American Heart Association. (2012). What are Heart Disease and Stroke ?. America: Diperoleh tanggal 11 April 2015 dari

6. American Heart Association.(2015). Coronary Artery Disease - Coronary Heart Disease. America:

Diperoleh tanggal 29 April 2015 dari

http://www.heart.org/HEARTORG/Conditions/More/MyHeartandStrokeNews/Coronary-Artery-

Disease---Coronary-Heart-Disease_UCM_436416_Article.jsp

7. Dharma, Kelana K. (2013).Metodologi Penelitian Keperawatan. Jakarta: Trans Info Media

8. Gray, H. H , Dawkins, K.D., Morgan, J.M. \& Simpson, I.A. (2005). Lectures Notes Kardiologi Edisi Keempat. Jakarta: EMS

9. Indrawati, Lina. (2012). Analisis Faktor Yang Berhubungan Dengan Kemampuan Pasien PJK Melakukan Pencegahan Sekunder faktor Risiko Di RSPAD Gatot Soebroto Jakarta.Tesis. Fakultas Ilmu Keperawatan Universitas Indonesia

10. Irianto, Koes. (2014). Memahami Berbagai Macam Penyakit. Bandung: Alfabeta

11. Jackson, M., \& Jackson, L. (2011).Seri Panduan Praktis Keperawatan Klinis. Jakarta: Erlangga Medical Series

12. Notoatmodjo, Soekidjo. (2012). Metodologi Penelitian Kesehatan. Jakarta: Rineka Cipta

13. Riskesdas.(2013). Riset Kesehatan Dasar. Diperoleh tanggal 1 April 2015 dari http://www.google.co.id/url?sa=t\&rct=j\&q=\&esrc=s\&source=web\&cd=1\&cad=rja\&uact=8\&ved=0CBs QFjAA\&url=http\%3A\%2F\%2Fwww.depkes.go.id\%2Fresources\%2Fdownload\%2Fgeneral\%2FHasil\% 2520Riskesdas\%25202013.pdf\&ei=0OudVd3rIYqWuATVnYioDA\&usg=AFQjCNH5N0m5ze5bOvcF 9ja9z4da6wpXyQ\&sig2=q3GWDh3hiQDYemLpNg5thA

14. Rochmayanti.(2011). Analisis Faktor-Faktor Yang Mempengaruhi Kualitas Hidup Pasien Penyakit Jantung Koroner Di Rumah Sakit Pelni Jakarta.Skripsi. Depok: Program Magister Ilmu Keperawatan Perminatan Keperawatan Medikal Bedah Universitas Indonesia 
15. Rosmiatin, Mira. (2012). Analisis Faktor - Faktor Risiko Terhadap Kejadian Penyakit Jantung Koroner Pada Wanita Usia Lanjut Di RSUPN Dr. Cipto Mangunkusumo Jakarta. Tesis. Fakultas Ilmu Keperawatan Universitas Indonesia

16. Soeharto, Iman. (2001). Pencegahan \& Penyembuhan Penyakit Jantung Koroner (cet. ke-2). Jakarta: Gramedia Pustaka Utama

17. Supriyono, Mamat. (2008). Faktor-Faktor Risiko Yang Berpengaruh Terhadap Kejadian Penyakit Jantung Koroner Pada Kelompok Usia $\leq 45$ Tahun Di RSUP Dr. Kariadi Dan RS Telogorejo Semarang. Tesis. Program Pasca Sarjana - Magister epidemiologi Universitas Diponegoro Semarang 